\title{
Indications for interferon/ribavirin therapy in hepatitis C patients: Findings from a survey of Canadian hepatologists
}

\author{
Peter Wang MD PhD(c) $)^{1}$, Qilong Yi MD PhD ${ }^{2}$, Linda Scully MD FRCPC ${ }^{3}$, \\ Jenny Heathcote MD FRCPC ${ }^{4}$, Murray Krahn MD MSc FRCPC ${ }^{1}$
}

\begin{abstract}
P W ang, Q Yi, L Scully, J H eathcote, M Krahn. Indications for interferon/ribavirin therapy in hepatitis $C$ patients: Findings from a survey of Canadian hepatologists. C an J G astroenterol 2003;17(3):183-186.
\end{abstract}

OBJECTIVE: To survey practising hepatologists about their attitudes and practices regarding interferon and ribavirin combination therapy for hepatitis C ( HCV) patients in Canada.

MET H OD S: A nonymous fax and mail survey in Canada. The questionnaire consisted of two sets of questions: the likelihood (in percentage) of treating a patient with certain clinical characteristics; and opinions (Yes/No) regarding how his/her treatment decision is influenced by other factors (ie, patient age, genotype). Thirty-eight of 44 eligible participants responded to the survey with a response rate of $86.4 \%$.

RESU LT S: M ost participants indicated that they were likely to treat patients with "moderate/severe hepatitis with fibrosis" (median $80.0 \%$ ), and compensated cirrhosis (median $75 \%$ ). H owever, the participants were less willing to treat patients with coexisting conditions (median $25.0 \%$ ) or mild hepatitis (median 13.8\%).

CON C L U SIO N S: The findings from the present study indicate that there is a substantial variation in opinion among $C$ anadian hepatologists towards treating HCV patients. The present study, however, suggests that the survey respondents appear, in general, to adhere to the HCV treatment guidelines by the Canadian A ssociation for Study of the Liver.

Key Words: Hepatitis C; Interferon; Practice guidelines; Practice patterns; Survey; T herapy

\section{Les indications en faveur d'un traitement à l'interféron et à la ribavirine chez les patients atteints d'hépatite $C$ : 0 bservations découlant d'une enquête auprès d'hépatologistes cana- diens}

OBJECT IF : Faire une enquête auprès des hépatologistes en exercice au sujet de leurs attitudes et de leurs pratiques quant à l'association d'interféron et de ribavirine chez les patients atteints d'hépatite C (VHC) au $C$ anada.

MÉTHODOLOGIE : Enquête anonyme par la poste et par télécopieur au $\mathrm{C}$ anada. Le questionnaire se composait de deux séries de questions : la probabilité (en pourcentage) de traiter un patient présentant certaines caractéristiques cliniques et le fait que la décision de traitement soit influencée ou non par d'autres facteurs ( $p$. ex., âge du patient, génotype). Trente-huit des 44 participants admissibles ont répondu à l'enquête, pour un taux de réponse de $88 \%$.

RÉ SU LTAT S : La plupart des participants ont indiqué qu'ils étaient susceptibles de traiter des patients présentant une « hépatite modérée à grave accompagnée de fibrose » (moyenne de $80 \%$ ) et une cirrhose compensée (moyenne de $75 \%$ ). C ependant, les participants étaient moins disposés à traiter des patients présentant des pathologies coexistantes (moyenne de $25,0 \%$ ) ou une hépatite bénigne (moyenne de $13,8 \%$ ).

C O N C L U SION S : Les observations découlant de cette enquête révèlent une variation substantielle d'opinions parmi les hépatologistes canadiens dans le traitement des patients atteints du VHC. Toutefois, l'enquête indique qu'en général, les répondants semblaient adhérer aux directives de traitement du VHC par l'A ssociation canadienne pour l'étude du foie. nfection with hepatitis C (HCV) is one of the most common causes of liver disease, affecting approximately $1 \%$ of the $C$ anadian population $(1,2)$, and is the single most common reason for liver transplantation (3). In the past several years, the management of chronic HCV infection has evolved rapidly and antiviral treatment has become an important aspect of care for people infected with HCV. A number of recent, large clinical trials have shown that in comparison with interferon monotherapy, interferon/ribavirin combination treatment has significantly increased the sustained response rates in patients with chronic HCV $(3,4)$. Thus, interferon/ribavirin treatment has become a mainstream clinical modality in treating chronic HCV patients. $\mathrm{H}$ owever, little is known regarding how $\mathrm{C}$ anadian hepatologists prescribe the combination to their HCV patients and how various disease-related (eg, disease stage) and patient-related factors (eg, age and comorbidity) influence hepatologists' clinical decision-making. Little is known also about clinicians' adherence to guidelines regarding antiviral therapy, such as the newly developed chronic HCV treatment guidelines by the Canadian A ssociation for Study of the Liver (CA SL) (5).

$\mathrm{C}$ anadian liver specialists were surveyed to gain knowledge of the current clinical practice regarding interferon and rib-

${ }^{1}$ T he Toronto $\mathrm{G}$ eneral H ospital; ${ }^{2} \mathrm{O}$ ntario $\mathrm{C}$ ancer Institute/Princess $\mathrm{M}$ argaret $\mathrm{H}$ ospital, U niversity H ealth $\mathrm{N}$ etwork; ${ }^{3}$ Toronto W estern $\mathrm{H}$ ospital, $\mathrm{U}$ niversity $\mathrm{H}$ ealth $\mathrm{N}$ etwork, Toronto, $\mathrm{O}$ ntario; ${ }^{4} \mathrm{D}$ ivision of $\mathrm{G}$ astroenterology, $\mathrm{T}$ he $\mathrm{O}$ ttawa $\mathrm{H}$ ospital, $\mathrm{O}$ ttawa, $\mathrm{O}$ ntario

C orrespondence: D r M urray K rahn, The Toronto G eneral H ospital, EN G -248, 200 Elizabeth Street, Toronto, 0 ntario M 5 G 2 C 4.

Telephone 416-340-4155, fax 416-595-5826, e-mail murray.krahn@uhn.on.ca

Received for publication July 9, 2002. A ccepted D ecember 10, 2002 
TABLE 1

Hepatologist-reported proportion of patients with hepatitis $\mathbf{C}$ receiving interferon/ribavirin combination in their clinical practice: Findings from 2001 Canadian hepatologist survey $(n=38)$

\begin{tabular}{|c|c|c|c|c|}
\hline & Median & Mean & & \\
\hline $\begin{array}{l}\text { 1. What percentage of all patients are not eligible because } \\
\text { of coexisting conditions (eg depression, heart disease, } \\
\text { continuing alcohol and drug abuse)? }\end{array}$ & $\begin{array}{c}25.0 \\
(20.0,32.5)\end{array}$ & $\begin{array}{c}30.1 \\
(24.3,35.9)\end{array}$ & 5 & 75 \\
\hline $\begin{array}{l}\text { 2. What percentage of all patients with } \\
\text { hepatitis } C \text { do you treat? }\end{array}$ & $\begin{array}{c}40.0 \\
(33.0,50.2)\end{array}$ & $\begin{array}{c}43.6 \\
(37.5,49.7)\end{array}$ & 10 & 85 \\
\hline $\begin{array}{l}\text { 3. What percentage of patients with } \\
\text { normal enzymes do you treat? }\end{array}$ & $\begin{array}{c}1.5 \\
(0.0,5.0)\end{array}$ & $\begin{array}{c}6.0 \\
(2.9,9.1)\end{array}$ & 0 & 45 \\
\hline $\begin{array}{l}\text { 4. What percentage of patients with mild hepatitis/ } \\
\text { nonfibrosis do you treat? }\end{array}$ & $\begin{array}{c}13.8 \\
(10.0,30.0)\end{array}$ & $\begin{array}{c}28.7 \\
(19.2,38.2)\end{array}$ & 0 & 100 \\
\hline $\begin{array}{l}\text { 5. What percentage of patients with moderate-severe } \\
\text { hepatitis with fibrosis do you treat? }\end{array}$ & $\begin{array}{c}80.0 \\
(75.0,95.0)\end{array}$ & $\begin{array}{c}76.7 \\
(68.6,84.8)\end{array}$ & 12.5 & 100 \\
\hline $\begin{array}{l}\text { 6.What percentage of patients with well } \\
\text { compensated cirrhosis do you treat? }\end{array}$ & $\begin{array}{c}75.0 \\
(50.0,90.0)\end{array}$ & $\begin{array}{c}62.0 \\
(49.9,74.1)\end{array}$ & 0 & 100 \\
\hline $\begin{array}{l}\text { 7. What percentage of patients with } \\
\text { decompensated cirrhosis do you treat? }\end{array}$ & $\begin{array}{c}0.0 \\
(0.0,0.0)\end{array}$ & $\begin{array}{c}3.8 \\
(0.4,7.2)\end{array}$ & 0 & 50 \\
\hline
\end{tabular}

avirin combination therapy for HCV patients in Canada, and to provide insights regarding adherence to published guidelines.

\section{METHODS}

Fifty-four clinicians with special expertise in liver diseases (hepatology) were identified through two steps. First, the latest version of the $C$ anadian Medical Directory (CMD) on CD-Rom (6), which contains information regarding 58,621 currently practicing $C$ anadian physicians, was used for a comprehensive search. Based on their practices, physicians were grouped into their corresponding main specialities (one or more). A Ithough CM D allows searches by 60 specialities (eg, cardiology and rheumatology) and 45 subspecialties (eg, diabetes, pain management), hepatology was not indexed as a main or subspecialty. Thus, a systematic search was conducted in the specialties of gastroenterology, infectious diseases, endocrinology and pediatrics, searching for text with any mention of hepatology, hepatitis or liver disease in the specialty description. In total, 43 potential hepatologists were identified from the 2002 C M D. Of this group, $79 \%$ were identified as liver specialists (with or without an additional descriptor; eg, gastroenterologist), 13\% were identified as gastroenterologists and $8 \%$ were identified as internists.

A s another independent source, two of the present coauthors ( $\mathrm{LS}$ and JH) were asked to provide names of active hepatologists based on their knowledge of colleagues across the country. A $n$ additional 11 active hepatologists, who were all listed as gastroenterologists in the CM D, were identified. A one-page questionnaire along with a cover letter outlining the study objectives was sent to all eligible hepatologists across 10 provinces between $\mathrm{N}$ ovember 2001 and January 2002 via fax ( $85 \%$ ), or by mail (15\%) when fax numbers were not available.

The survey requested information regarding current practice patterns using interferon/ribavirin combination therapy. Participants were al so asked to take into account any changes that they would make based on the availability of pegylated interferon in the near future. The questionnaire consisted of two sets of questions:

- The likelihood (in percentage) of treating a patient at various stages; and
- O pinions (Yes/No) regarding how his/her treatment decision is influenced by other factors (ie, patient age, genotype)

A ll questionnaires were anonymous and no personal characteristics (ie, age, sex and years in practice) were asked in the survey. Demographic characteristics were obtained from the CMD. A reminder letter along with a stamped return envelope and the original questionnaire was sent to all nonresponders four weeks after the initial contact.

\section{A N A LY SES}

Simple descriptive statistics were used to describe central tendency (mean, median) and range for each survey item. The $95 \% \mathrm{CI}$ for means were calculated using the conventional normal distribution method. Because there is no available statistical formula to directly calculate the $95 \% \mathrm{CI}$ for medians, a bootstrap approach was employed $(7,8)$. This technique involved dividing the total participants into subgroups (replicates), from which a random sample is taken with replacement and a new median was calculated each time. A fter a large number of such experiments, the lower and upper $95 \% \mathrm{CI}$ were determined from the values at $2.5 \%$ and $97.5 \%$ percentiles. A II the calculations were performed using SA S 8.0 (SA S, USA) (9)

\section{RESU LT S}

Of the 54 potential participants, 10 were ineligible and excluded because they had retired (1), moved (4), were no longer treating $\mathrm{HCV}$ patients (3) or lacked correct contact information (2). In total, 38 participants responded, resulting in a response rate of $86.4 \%$. The mean length of clinical practice (based on the year of graduation) for the 38 eligible participants was 21.5 years with a SD of 10.3 years. $N$ ineteen per cent were women and $82.4 \%$ reported liver disease as the major component of their practice.

Table 1 provides summary estimates of the likelihood that a hepatologist in C anada would prescribe interferon/ribavirin therapy to a HCV patient at various stages. The results show a substantial variation in most questions. Most clinicians indi- 
TABLE 2

\begin{tabular}{|c|c|c|}
\hline Survey question & $\begin{array}{c}\text { Yes } \\
\text { n (\%) }\end{array}$ & $95 \% \mathrm{Cl}$ \\
\hline $\begin{array}{l}\text { Would you treat a patient older } \\
\text { than } 65 \text { years of age? }\end{array}$ & $26(68.4)$ & $53.6,83.2$ \\
\hline $\begin{array}{l}\text { Does the genotype influence your } \\
\text { decision to treat patients? }\end{array}$ & $21(55.3)$ & $39.5,71.1$ \\
\hline $\begin{array}{l}\text { Do you biopsy all patients before } \\
\text { treatment? }\end{array}$ & $26(68.4)$ & $53.6,83.2$ \\
\hline
\end{tabular}

cated that they were likely to treat patients with "moderate/severe hepatitis with fibrosis" (median 80.0\%, 95\% CI $75.0 \%, 95.0 \%$ ) and compensated cirrhosis (median $75 \%$, $95 \%$ Cl 50.0\%, 90.0\%). H owever, participants were less willing to treat patients with coexisting conditions (median $25.0 \%$ ) or mild hepatitis (median $13.8 \%$ ). Hepatologists were very unlikely to treat patients with decompensated cirrhosis (median or mean values of 0.0 ).

More than one-third of hepatologists $(68.4 \%, 95 \% \mathrm{Cl}$ $53.6 \%, 83.2 \%$ ) did not regard the age of 65 years as a cut-off point in terms of treatment decision-making. N evertheless, $55.3 \%(95 \% \mathrm{Cl} 39.5 \%, 71.1 \%)$ of the surveyed hepatologists reported that genotype would influence their decision to treat patients; $68.4 \%(95 \%$ CI 53.6\%,83.2\%) reported they would biopsy all patients before treatment (Table 2).

A $n$ open-ended question was embedded in this survey asking "W hat patient criteria (laboratory or clinical) would prevent you from using interferon/ribavirin?" Hematological disorders, such as low platelets or neutrophils, were the most common response ( $87.1 \%$ ). Other frequently indicated conditions were severe depression or other psychiatric disorders $(67.7 \%)$, drug abuse $(45.2 \%)$, advanced liver disease, such as decompensation and liver cancer (35.5\%), and heart disease $(25.8 \%)$.

\section{COMMENTS}

Findings from the present study indicate that there is a substantial variation in opinion among Canadian hepatologists towards treating HCV patients. The present study also suggests, however, that survey respondents do appear, in general, to adhere to published guidelines in their practice recommendations.

\section{Severity of liver disease}

A ccording to the CASL guidelines, the prime indication for treatment in chronic HCV is three consecutive abnormal alanine aminotransferase levels ( 1.5 times the upper limit of normal) over more than three months. Patients with normal alanine aminotransferase levels usual ly have an excellent prognosis and treatment is not recommended (5). The guidelines are not very explicit with respect to treatment indications by severity of liver fibrosis or inflammation. A ccording to the guidelines, patients with normal or minimal fibrosis are not normally considered to be treatment candidates, and decompensated liver disease is regarded as an absolute contraindication. However, there is less clarity as to whether and which patients with more severe fibrosis or compensated cirrhosis should be treated.
Clinicians adhere to the CA SL guidelines with respect to patients with normal enzymes. Only $1.5 \%$ (median) of such patients would receive interferon/ribavirin. The results also indicate good adherence to the guidelines in managing patients with decompensated liver disease, because very few (median $0.0 \%$ ) of those patients are treated. Given the lack of guidance with respect to intermediate stages of liver disease (moderate-severe hepatitis, compensated cirrhosis), it is difficult to comment on adherence for this group. However, wide practice variation among clinicians was observed for these patients (range $0 \%$ to $100 \%$ ) and future guidelines should address this question specifically.

Survey respondents appeared to be aware of the importance of genotype and liver biopsy in treatment decisions. A Ithough the guidelines do not explicitly mandate liver biopsy, it declares that "the only method to stage HCV accurately is by liver biopsy". That $71 \%$ of survey respondents biopsy all patients before treatment indicates that the importance of liver biopsy for accurate staging and prognosis is widely accepted. The CA SL guidelines indicate that treatment is more effective for genotypes 2 and 3 , and recommends shorter treatment regimens in this group. H owever, no recommendations are offered regarding how genotype information should be incorporated into the decision to offer or withhold treatment. Clinicians are split on this issue, with over half ( $55.3 \%$ ) considering gen otype in the treatment decision.

\section{Patient factors}

The CA SL guidelines do not define age limits for treatment, but do, nonetheless, mention a specific age threshold of 50 years. The guidelines indicate that this threshold is an important factor in determining whether combination treatment should be offered, because competing causes of mortality are more likely to cause death in patients older than 50 years. Clinicians also appeared to appreciate the role played by comorbid disease (eg, depression, cardiovascular disease), as manifested in the reported percentage of patients believed to be ineligible on these grounds, and the comments regarding barriers to treatment.

\section{Temporal trends}

The results of the present survey were similar to those in a similar (unpublished) survey completed among a convenience sample of 12 Canadian hepatologists in 1999. Very similar mean percentages of patients were believed to be ineligible because of comorbidity (30\% versus $30 \%$ ), and similar percentages of patients with normal enzymes ( $6 \%$ versus $12 \%$ ) and mild hepatitis (29\% versus $32 \%$ ) would be treated. H owever, there appeared to be a trend toward more aggressive treatment of patients with more advanced disease in the 2002 survey. A mong patients with moderate-severe disease, $77 \%$ versus $45 \%$ would be treated; in well compensated cirrhosis, $62 \%$ versus $40 \%$ would be treated; and among patients with decompensated cirrhosis, $4 \%$ versus $1 \%$ would be treated.

\section{CONCLUSIONS}

The present survey has limitations. We considered a limited number of factors, and did not exhaustively explore the role of all potential disease-related and patient-related factors. The role of human immunodeficiency virus, geographical, demo- 
graphic and economic barriers to treatment, such as varying provincial reimbursement policies for antiviral therapy, were not considered. We could not evaluate the extent to which physician disagreement with published guidelines accounted for practice that deviated from that suggested by guidelines. Survey responses often differ from actual prescribing practice. $\mathrm{N}$ onethel ess, given the completeness of the sample and the relatively high response rate for a physician survey, we believe that the present survey presents an accurate, if brief, snapshot of the factors used by $\mathrm{C}$ anadian liver specialists in allocating antiviral treatment for $\mathrm{HCV}$ patients. It also demonstrates that

\section{REFEREN CES}

1. H ealth $C$ anada. The prevalence of hepatitis $C$ in a communitybased population, O ntario, 1996. C anada Communicable Disease Report. Ottawa: H ealth C anada, 1999 <http://www.hcsc.gc.ca/pphb-dgspsp/publicat/ccdr-rmtc/99vol25/dr2523e.html> (Version current at January 23, 2003)

2. Remis R, Hogg R, Krahn M, Preiksaitis J, Sherman M. Estimating the number of blood transfusion recipients infected by hepatitis $C$ virus in C anada, 196-1985 and 1990-1992. Report to H ealth Canada: 1998.

3. Gutfreund K, Bain V. Chronic viral hepatitis C: M anagement update. CM AJ 2000;162:827-33.

4. Heathcote J. A ntiviral therapy for patients with chronic hepatologists in general do adhere to the CA SL guidelines on treatment. Finally, heterogeneity in practice patterns in certain groups (eg, patients with mild to moderate fibrosis) suggests that future iterations of treatment guidelines may benefit from a greater degree of specificity, so as to allow patients to be offered consistent treatment recommendations based directly on evidence.

A C KN OWLEDGEMENTS: The authors wish to thank all participants, whose participation and support made this study possible.

hepatitis C. Semin Liver Dis 2000;20:185-99.

5. C anadian consensus conference on the management of viral hepatitis. C anadian A ssociation for the Study of the Liver. Can G astroenterol 2000;14 (Suppl B):5B-20B

6. The Canadian M edical Directory on CD-ROM. Southam Information Products G roup: Toronto, 2001.

7. Efron B, Tibshirani R. A n Introduction to the Bootstrap. $\mathrm{N}$ ew York: Chapman \& Hall, 1993.

8. Lohr SL. Sampling: Design and A nalysis. Pacific Grove: Duxbury Press, 1999.

9. SA S Institute. SA S/STAT user's guide, version 8. Cary: SA S Institute, 1999 


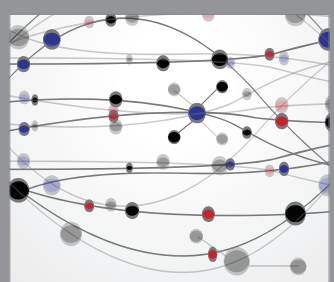

The Scientific World Journal
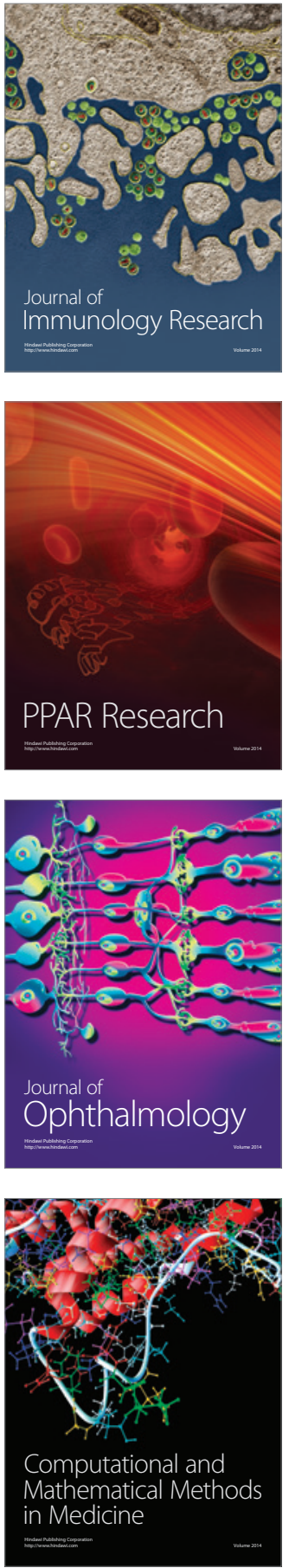

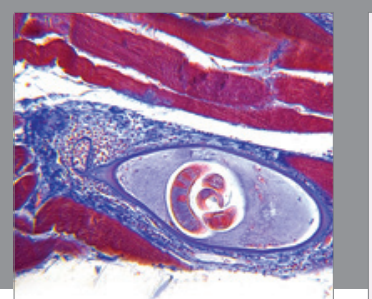

Gastroenterology Research and Practice

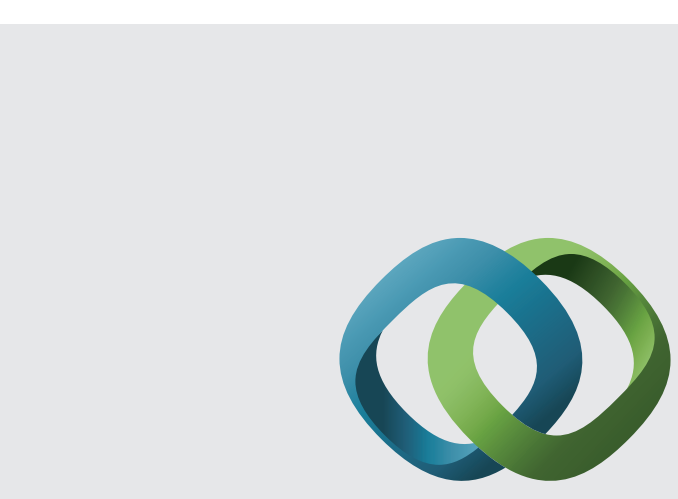

\section{Hindawi}

Submit your manuscripts at

http://www.hindawi.com
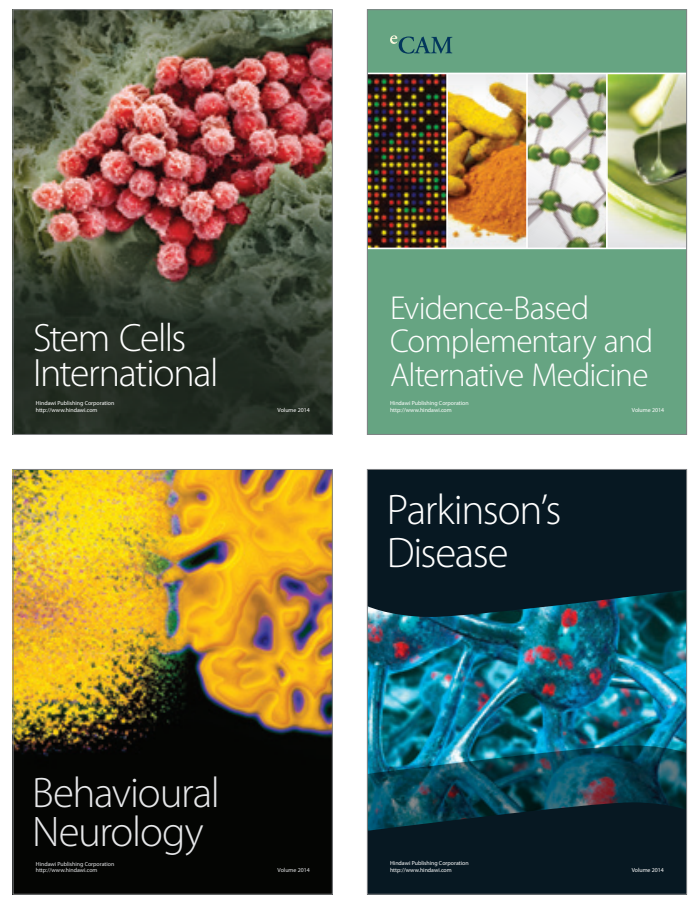
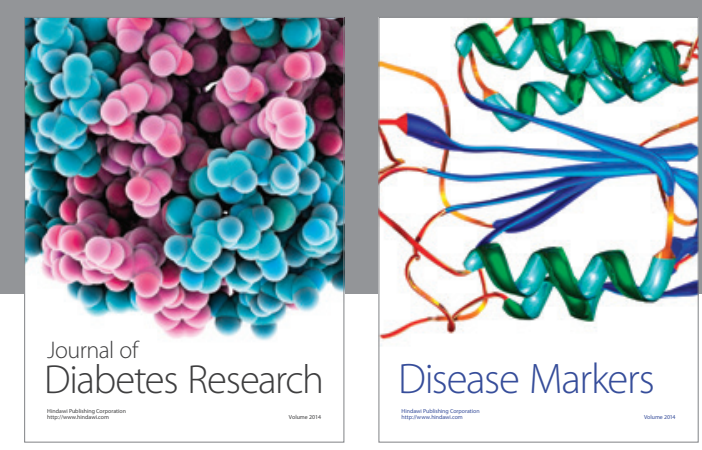

Disease Markers
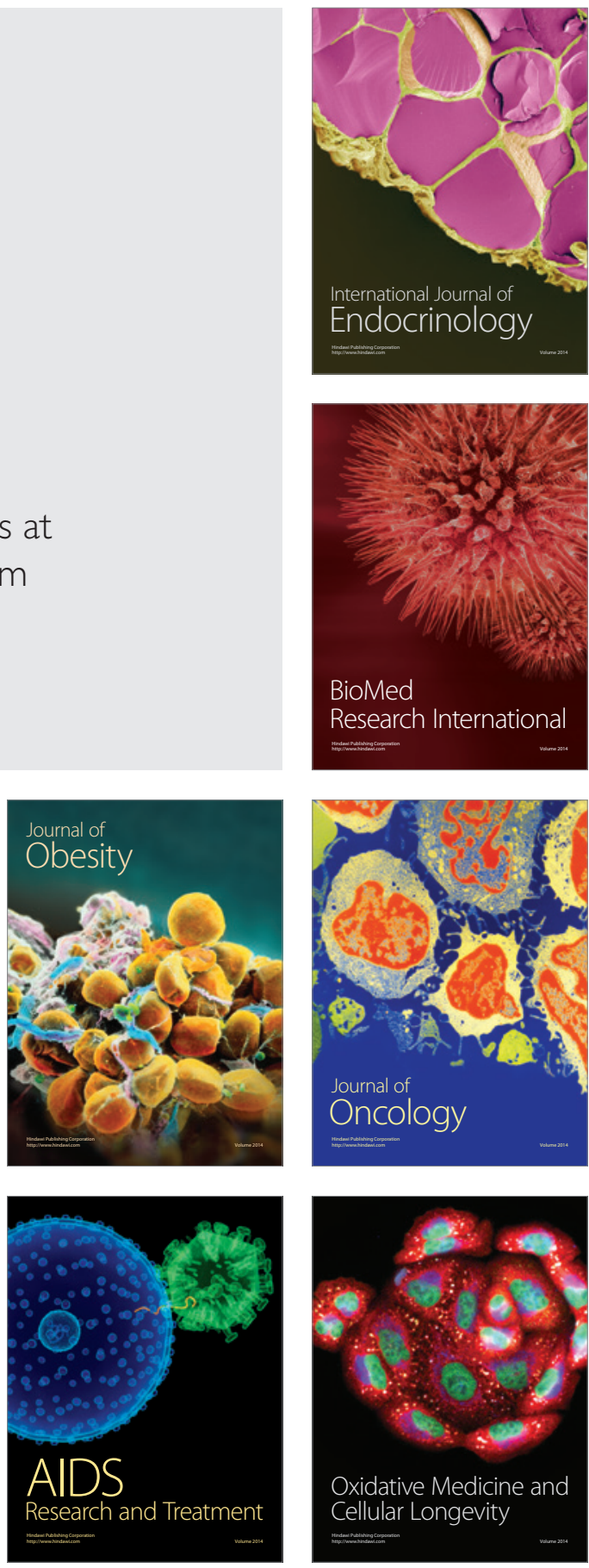